\title{
Behavioural Responses in Mudskipper (Periopthalmus Papilio) Exposed to Sodium Bromide under Laboratory Conditions
}

\author{
Nte $\mathrm{ME}^{1}$, Edun $\mathbf{O M}^{2}$ and Akinrotimi $\mathbf{O A}^{3^{*}}$ \\ ${ }^{1}$ Department of Animal and Environmental Biology, Faculty of Science, University of Port Harcourt, Rivers State, \\ Nigeria \\ ${ }^{2,3^{*}}$ African Regional Aquaculture Center of Nigerian Institute for Oceanography and Marine Research, Port Harcourt, \\ Rivers State, Nigeria
}

Received: December 1, 2017; Accepted: December 15, 2017; Published: January 1, 2018

*Corresponding author: Akinrotimi OA, African Regional Aquaculture Center of Nigerian Institute for Oceanography and Marine Research, P.M.B.5122, Port Harcourt, Rivers State, Nigeria, Tel: +2348065770699; E-mail: ojoakinrotimi@gmail.com

\begin{abstract}
One hundred and eighty (180) mudskipper (Periophthalmus papilio) of equal size (mean length $18.74 \pm 2.64 \mathrm{~cm}$ and mean weight $156.68 \pm$ $1.81 \mathrm{~g})$ were exposed to different concentrations $(0.0 \mathrm{mg} / \mathrm{l}$ - control, 5.0 $10.0,15.0,20.0$ and $25.0 \mathrm{mg} / \mathrm{l}$ ) of sodium bromide a biocide, to determine the Behavioural responses of opercula beat frequency (OBF), tail beat frequency (TBF), 96 hour lethal concentration $\left(96 \mathrm{~h} . \mathrm{LC}_{50}\right.$ and median lethal time $\left(\mathrm{MLT}_{50}\right)$. The result obtained indicated that P. papilio showed initial stress responses such as increased opercula ventilator rate, erratic swimming and gasping for air. The pattern of response of TBF to time and concentrations of the biocide was irregular, whereas that of OBF tended to decrease with increase in time, but increased with increase in concentrations. Also cumulative mortality values increased with exposure time and concentrations.
\end{abstract}

\section{Introduction}

Aquatic systems are the final recipient of both natural and artificial inputs of pollutants into the environment. Releases of toxic substances such as chemicals have been responsible for the reduction in the populations of aquatic organisms across the globe. Even sub-lethal concentrations of toxicants may prove to be equally devastating to fish populations $[1,2]$. The upsurge in human activities is one of the main factors leading to the increasing level of contaminants in aquatic environments. Coastal pollution has been increasing significantly over the recent years and further expanding environmental problems in many developing countries. The discharge of waters from cites, public places and industries have resulted in pollution of aquatic ecosystems $[3,4]$.

Fishes are exposed to pollutants through water and in their feeding patterns. They enter their bodies through the skin, gills and even via the mother in uteri [5]. One of the most insidious characteristics of pollutants is that because they are lipid - soluble they tend to accumulate in animal body tissues. This problem is further compounded by the process of biomagnifications in which chemical concentrations increase at higher tropic levels
[6]. In amphibians contaminant concentration are often many time greater in body tissue than those in the surrounding waters [7]. Chemicals from house hold and industrial sources have been recognized as one of the major pollutants in the aquatic bodies [8]. One of such chemicals whose utilization cut across home and industries is biocide.

The use of biocides is indispensable in modern agricultural technology to control weeds or pests for the production of more food and management of public health. Biocides such as sodium bromide are routinely employed to control the growth and development of fouling organisms. In water cooling systems the working life of a biocide depends on environmental factors, the amount added, the physical and chemical fate of the compound. Unfortunately, there exists residual quantities of biocides and their degradation/ transformation present in the effluents of these systems, are sometimes discharged into rivers, creeks, estuaries and lagoons [9].

Benli, et al. defined Behavioural toxicity as a change, which is induced by stress that exceeds the homeostasis [10]. It is believed that Behavioural changes in fish are the most sensitive measures of neurotoxicity and this may have motivated the large number of studies on animals [11]. Results from several investigations involving the use of several fish species support the concept that toxicant - induced stress on organisms can be quantified by methods other than mortality $[12,13,14]$. Hence, changes in fish behavior can be used as a sensitive indicator of acute and sub lethal toxicant exposure. Fish altered behaviors can be grouped as follows: a) Locomotors activity e.g. opercula beat frequency (OBF), tail beat frequency (TBF), (b) avoidance, (c) inhibition of feeding, (d) schooling, (d) migratory behavior (e) spawning and (f) homing. Some fish behaviors (e.g. locomotors and avoidance) are extremely sensitive to pollutant chemicals, whereas others (e.g. aggression, feeding and spawning) seem to be refractory [15]. 
Mudskipper Periophthalmus Papilio is an amphibious fish that is highly active during low tides and spend most of its time out of water in mangrove habitats. According to Akinrotimi et al. [16] they form a high density on tidal mud flats in the coastal areas of Niger Delta. This species is widely distributed and notably present in many reverie communities in Niger Delta, Nigeria, thus, it is essential to evaluate the toxicity of biocides in the fish, as many research activities in coastal environment have been focusing on other species. Hence, the present investigation is aimed to assess the physiological responses of the mudskipper P. Papilio exposed to the biocide, sodium bromide in order to understand the biocide mode of action, stress responses and organ dysfunction in experimental fish.

\section{Materials and Methods}

\section{Experimental Location}

The experiment was carried out at the brackish water research station of African Regional Aquaculture Centre, Buguma, and Rivers State, Nigeria.

\section{Source of Experimental Fish}

One hundred and eighty (180) adult, mudskipper P.Papilio of equal size (mean length $18.74 \pm 2.64 \mathrm{~cm}$ and mean weight $156.68 \pm 1.81 \mathrm{~g}$ ) was collected from the mangrove swamps in Buguma creek at low tide using locally made fishing trap. They were then transferred in six 50 liter plastic tanks to the laboratory for acclimation process.

\section{Acclimation and Feeding Of Fish}

The experimental fish was acclimated in four 150L capacity circular plastic tanks containing 150L de-chlorinated water for and mud at the bottom, 7 days to experimental conditions at room temperature Netted materials with central slits was tied to the tops of the tanks to prevent escape of fish. Water renewal was done every two days. The fish were feed with freshly killed crabs, cut into small pieces.

\section{Procurement of Test Solution}

A commonly used biocide sodium bromide $(\mathrm{NaBr})$ was purchased off shelf, from "Analytical" chemical shop, Garrison, Port Harcourt, Rivers State, Nigeria. Sodium bromide is an inorganic compound with the formula $\mathrm{NaBr}$. It is a high-melting white, crystalline solid that resembles sodium chloride. It is a widely used source of bromide ion and has many applications.

\section{Preparation of Test Solution}

The solution of the chemical in water was prepared by serial dilution using the dilution formula described by Begum [17].

\section{Exposure of Fish to Biocide Sodium Bromide}

10 Mudskippers each were introduced individually into 18 , tanks of dimension $1.5 \mathrm{~m} \times 1 \mathrm{~m} \times 0.5 \mathrm{~m}$ containing various concentrations of biocide: 0.00 (control), 5.00, 10.00, 15.00, 20.00 and $25.00 \mathrm{mg} / \mathrm{L}^{-1}$. Each treatment(s) and control was replicated three times and the experimental duration lasted for a period of 96 hours. The solution for each concentration was renewed daily, with freshly prepared solution of biocide. The tanks were covered with netted materials and supported with heavy objects to prevent the mudskipper from escaping. Opercula beat frequency (OBF), Tail beat frequency (TBF) and mortality was monitored at fixed intervals of $12,24,36,48,60,72,84$ and 96 hours. Dead fish were counted at $12 \mathrm{~h}$ intervals and revived from aquaria. A fish was considered dead when it showed no visible movement (e.g. gill movements) and touching its caudal peduncle did not produce any reaction.

\section{Evaluation of Water Quality Parameters}

Temperature measurements were made with a mercury-filled Celsius thermometer. $\mathrm{PH}$ was done with $\mathrm{pH}$ meter. Electrical conductivity and nitrate of both effluent and the water samples were determine using Horiba water checker (Horita U-10 models). While phosphate and ammonia was measured using a test kit with a calorimetric chant produced by SUNPV, Biochem, Beijin China and the salinity was evaluated using hand held refractometer (model HRN-2N, Atago, Products, Japan). This was done by dropping two drops of water and effluents on refractive glass and then viewed from the back side, the reading were then recorded. Biological water samples for Oxygen Demand (BOD) were incubated for 5 days in the dark at room temperature. Then the Winkler's method (APHA [18]) was then used.

\section{Statistical Analysis}

Data obtained from the experiments were subjected to ANOVA using Statistical Package for the Social Sciences, (SPSS) version 10 and differences among means were separated by Duncan Multiple Range test at $0.05 \%$. The dependent variables in the trials $(\mathrm{OBF}, \mathrm{TBF}$, mortality, blood parameters and biochemical indices) were compared based on the concentration of the toxicants. An analysis of the lethal concentration (LC50) values for the 24, 48, 72 and 96 hours and the median lethal time for the various concentrations of herbicide was done with Probity Analysis. Safe concentration of the herbicide at the various time intervals were obtained by multiplying the lethal concentration by a factor 0.1 [19].

\section{Results}

\section{Water Quality Parameters}

The result of the physico-chemical properties of the exposure tanks in chronic toxicity studies are presented in table 1 . The water quality variables in the aquaria of $P$. Papilio exposed to sodium bromide for 96 hours indicated a significant reduction $(p<0.05)$ in the values of dissolved oxygen. Also, significant increases with increasing concentration of the chemical were however recorded in the values of ammonia, electrical conductivity. Chloride, sulphide and total hardness of water. While other parameters such as temperature, $\mathrm{pH}$ and salinity were within the same range comparable to the control at all concentrations of the chemical.

\section{General Behavioural Changes}

As fish came into contact with the toxicant, abnormal behavior was observed. The abnormal behavior exhibited was a Neural Paralytic Syndrome (NPS). Strong restlessness and 


\begin{tabular}{|c|c|c|c|c|c|c|}
\hline \multicolumn{6}{|c|}{ Concentrations of Sodium Bromide $\left(\mathrm{MIL}^{-1}\right)$} & \multirow[b]{2}{*}{25.0} \\
\hline Parameters & 0.0 & 5.0 & 10.0 & 15.0 & 20.0 & \\
\hline Temperature ${ }^{\left({ }^{\circ}\right)}$ & $27.37 \pm 4.21^{\mathrm{a}}$ & $27.68 \pm 4.21^{\mathrm{a}}$ & $27.49 \pm 4.11^{\mathrm{a}}$ & $27.74 \pm 4.12^{\mathrm{a}}$ & $28.02 \pm 1.18^{\mathrm{a}}$ & $27.61 \pm 1.18^{\mathrm{a}}$ \\
\hline $\mathbf{P h}$ & $6.38 \pm 1.67^{\mathrm{a}}$ & $6.36 \pm 1.24^{\mathrm{a}}$ & $6.33 \pm 1.18^{\mathrm{a}}$ & $6.36 \pm 1.24^{\mathrm{a}}$ & $6.39 \pm 1.34^{\mathrm{a}}$ & $6.37 \pm 1.17^{\mathrm{a}}$ \\
\hline Ammonia $\left(\mathrm{mgL}^{-1}\right)$ & $0.39 \pm 0.01^{\mathrm{a}}$ & $1.01 \pm 0.038^{b}$ & $0.49 \pm 0.04^{\mathrm{a}}$ & $1.03 \pm 0.01^{\mathrm{b}}$ & $1.06 \pm 0.01^{\mathrm{b}}$ & $1.12 \pm 0.18^{\mathrm{b}}$ \\
\hline Dissolved Oxygen $\left(\mathrm{mgL}^{-1}\right)$ & $6.78 \pm 1.12^{\mathrm{c}}$ & $5.81 \pm 0.81^{\mathrm{b}}$ & $6.13 \pm 0.91^{\mathrm{b}}$ & $3.88 \pm 1.16^{\mathrm{a}}$ & $3.24 \pm 1.34^{\mathrm{a}}$ & $3.02 \pm 1.018^{\mathrm{a}}$ \\
\hline Nitrite $\left(\mathrm{mgL}^{-1}\right)$ & $00.04 \pm 0.01^{\mathrm{a}}$ & $0.02 \pm 0.01^{\mathrm{ab}}$ & $0.009 \pm 0.02^{\mathrm{ab}}$ & $0.036 \pm 0.01^{\mathrm{c}}$ & $0.04 \pm 0.02^{\mathrm{a}}$ & $0.05 \pm 0.03^{\mathrm{a}}$ \\
\hline Sulphate $\left(\mathrm{mgL}^{-1}\right)$ & $0.02 \pm 0.01^{\mathrm{a}}$ & $0.04 \pm 0.01^{\mathrm{a}}$ & $0.02 \pm 0.01^{\mathrm{a}}$ & $0.05 \pm 0.01^{\mathrm{a}}$ & $0.06 \pm 0.02^{\mathrm{a}}$ & $0.07 \pm 0.01^{\mathrm{a}}$ \\
\hline Salinity $(0 / 00)$ & $10.88 \pm 1.68^{\mathrm{a}}$ & $10.87 \pm 1.24^{\mathrm{a}}$ & $10.81 \pm 1.02^{\mathrm{a}}$ & $10.81 \pm 1.02^{\mathrm{a}}$ & $10.89 \pm 1.12^{\mathrm{a}}$ & $10.88 \pm 1.11^{\mathrm{a}}$ \\
\hline $\begin{array}{l}\text { Electrical Conductivity } \\
\text { mmho/cm) }\end{array}$ & $\begin{array}{c}386.31 \pm \\
10.41^{\mathrm{a}}\end{array}$ & $398.61 \pm 11.21^{\mathrm{a}}$ & $383.61 \pm 12.61^{\mathrm{a}}$ & $42871 \pm 13.81^{\mathrm{b}}$ & $348.61 \pm 14.21^{\mathrm{a}}$ & $487.66 \pm 15.61^{\mathrm{c}}$ \\
\hline Chloride $\left(\mathrm{mgL}^{-1}\right)$ & $7.81 \pm 1.89^{\mathrm{a}}$ & $8.14 \pm 2.18^{\mathrm{a}}$ & $8.64 \pm 1.67^{\mathrm{a}}$ & $14.68 \pm 2.84^{\mathrm{ab}}$ & $20.61 \pm 241^{\mathrm{d}}$ & $24.68 \pm 3.18^{\mathrm{c}}$ \\
\hline Sulphide $\left(\mathrm{mgL}^{-1}\right)$ & $0.34 \pm 0.01^{\mathrm{a}}$ & $0.41 \pm 0.02^{\mathrm{a}}$ & $6.38 \pm 0.02^{\mathrm{a}}$ & $0.53 \pm 0.12^{\mathrm{b}}$ & $0.68 \pm 0.08^{c}$ & $0.78 \pm 1.18^{\mathrm{d}}$ \\
\hline Total Hardness $\left(\mathrm{mgL}^{-1}\right)$ & $19.74 \pm 1.21^{\mathrm{a}}$ & $24.68 \pm 1.18^{b}$ & $23.68 \pm 2.41^{\mathrm{ab}}$ & $28.61 \pm 3.14^{\mathrm{ab}}$ & $26.71 \pm 1.81^{\mathrm{db}}$ & $32.68 \pm 1.18^{c}$ \\
\hline
\end{tabular}

excitation was reflected by an increased reaction to exogenous stimuli, loss of movement co-ordination began as well as loss of orientation in water. Twisting of abdomen and weakening of jerks (areflexia) was also observed. Jumps above the water surface especially those that received the highest concentration of the toxicant, also rapid opercula movement and incessant gulping of air was obvious. There were no obvious changes in fish behavior in the lower concentrations (5.0, 10.0 and $15.0 \mathrm{mg} / \mathrm{L})$. These abnormalities displayed by fish increased with increasing concentration of sodium Bromide water but decreased with time/period of exposure.

\section{Behavior Responses (Opercula Beat Frequency and Tail Beat Frequency) and Mortality of P.Papilio exposed to Sodium Bromide for 96 hours}

The pattern of response of $\mathrm{OBF} / \mathrm{min}$ and $\mathrm{TBF}$ min to time of exposure and concentration of the toxicant were similar, it increased with time and concentration and latter decreased,

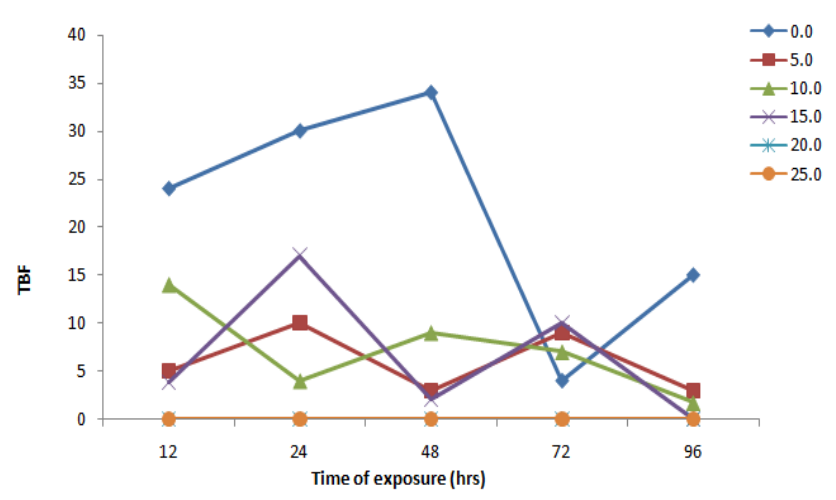

Figure 1: Tail beat frequency (TBF) in P.papillio exposed to various concentrations of sodium bromide for 96 hours

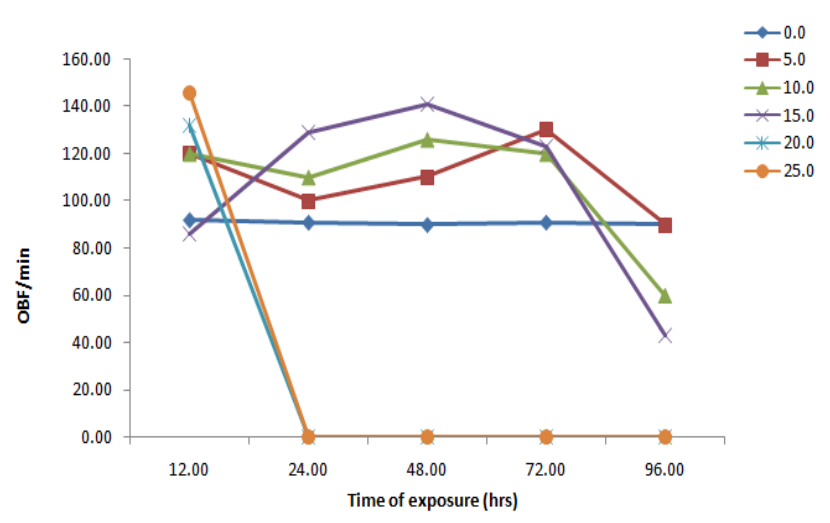

Figure 2: Tail beat frequency (TBF) in P.papillio exposed to various concentrations of sodium bromide for 96 hours

especially at the highest concentration and time (Figures 1 and 2). The range of variation of $\mathrm{OBF} / \mathrm{Min}$ and $\mathrm{TBF} / \mathrm{min}$ was similar, both were narrow. The cumulative mortality of the fish increased with time and was significantly different for the various time intervals and concentration.

Analysis of Variance (ANOVA) showed that various concentration extraction of biocide produced significant differences in the values of $\mathrm{OBF}$ and $\mathrm{TBF}(P>0.001)$ (Table 2 and $3)$. The time of exposure produced significant changes both in the OBF $(P>0.0001)$ and TBF $(P>0.001)$. Interaction between the exposure time and concentration of the toxicant produced marked changes in the OBF and TBF $(P>0.0001)$. ANOVA showed that the time of exposure $(P>0.001)$ interactions between exposure time and toxicant concentration $(P>0.0001)$ had no significant impact on the cumulative mortality of the fingerlings (Table 4). Mortality increased with time and concentration of the toxicant (Figure. 3). No morality was recorded in the control group. 
Table 2: Changes in the tail of opercula beat frequency and cumulative mortality (\%) of P. Papilio exposed to various concentration of Sodium Bromide for 96 hours (Mean \pm SD)

\begin{tabular}{|c|c|c|c|c|c|c|}
\hline \multirow[t]{2}{*}{ Variable } & \multicolumn{3}{|c|}{ Time of exposure (hrs) } & & & \\
\hline & 24 & 48 & 72 & \multicolumn{3}{|c|}{96} \\
\hline $\mathrm{TBF} / \mathrm{min}$ & $15.49 \pm 4.41^{\mathrm{ab}}$ & $7.87 \pm 4.41^{\mathrm{ab}}$ & $21.12 \pm 5.22^{\mathrm{b}}$ & \multicolumn{3}{|c|}{$4.49 \pm 5.40^{\mathrm{b}}$} \\
\hline $\mathrm{OBF} / \mathrm{min}$ & $113.10 \pm 7.60^{\mathrm{a}}$ & $115.23 \pm 7.23^{\mathrm{a}}$ & $10.79 \pm 899^{\mathrm{a}}$ & \multicolumn{3}{|c|}{$65.15 \pm 9.15^{b}$} \\
\hline Cum. Mortality & $37.227 \pm 31.21^{\mathrm{d}}$ & $56.11 \pm 36.16^{c}$ & $63.89 \pm 32.39^{b}$ & \multicolumn{3}{|c|}{$73.33 \pm 29.31^{\mathrm{a}}$} \\
\hline \multicolumn{7}{|c|}{ Concentration of Sodium bromide (Mg/L) } \\
\hline & $\mathbf{0}$ & 5 & 10 & 15 & 20 & 25 \\
\hline $\mathrm{TBF} / \mathrm{min}$ & $15.73 \pm 4.41^{\mathrm{a}}$ & $5.79 \pm 4.41^{\mathrm{a}}$ & $16.46 \pm 4.41^{\mathrm{b}}$ & $9.00 \pm 4.63^{b}$ & $7.04 \pm 5.92^{\mathrm{a}}$ & $0.00 \pm 0.00$ \\
\hline OBF/min & $96.71 \pm 7.60^{\mathrm{a}}$ & $123.27 \pm 8.00^{\mathrm{a}}$ & $108.58 \pm 800^{\mathrm{a}-\mathrm{c}}$ & $\begin{array}{c}100.93 \pm 8 \\
.00^{\mathrm{acc}}\end{array}$ & $\begin{array}{c}73.42 \pm 10 \\
.19^{c}\end{array}$ & $\begin{array}{c}124.72 \pm 16 \\
.99^{\mathrm{ab}}\end{array}$ \\
\hline Cum. Mortality & & $22.67 \pm 12.80^{\mathrm{d}}$ & $24.00 \pm 24.43^{\mathrm{d}}$ & $\begin{array}{c}32.67 \pm 19 \\
.81^{\mathrm{a}}\end{array}$ & $\begin{array}{c}50.67 \pm 37 \\
.70^{\mathrm{b}}\end{array}$ & $77.33 \pm 36.15^{\mathrm{d}}$ \\
\hline
\end{tabular}

Means with the same superscripts in the row are not significantly different $(P>0.05)$

Table 3: Mean squares from ANOVA of $\mathrm{OBF} / \mathrm{min}$., TBF/min. and cumulative mortality of P.Papilio exposed to sodium bromide (mean \pm SD)

\begin{tabular}{|c|c|c|c|}
\hline Source of variation & Dependent variable & df & Mean square \\
\hline \multirow[b]{3}{*}{ Time } & TBF & 4 & $0.017^{\mathrm{ns}}$ \\
\hline & $\mathrm{OBF}$ & 4 & $532.06^{* * *}$ \\
\hline & MORT & 4 & $2880.46^{* *}$ \\
\hline \multirow[b]{3}{*}{ Conc. } & TBF & 6 & $267.72^{\text {ns }}$ \\
\hline & $\mathrm{OBF}$ & 6 & $2757.12^{* *}$ \\
\hline & MORT & 6 & $1951.03^{* * *}$ \\
\hline \multirow[b]{3}{*}{ Time' Conc. } & TBF & 24 & $419.78^{\text {ns }}$ \\
\hline & $\mathrm{OBF}$ & 24 & $1335.49^{\mathrm{ns}}$ \\
\hline & MORT & 24 & $481.17^{* *}$ \\
\hline \multirow[b]{3}{*}{ Error } & TBF & 49 & 292.03 \\
\hline & $\mathrm{OBF}$ & 49 & 876.02 \\
\hline & MORT & 49 & 150.14 \\
\hline
\end{tabular}

TBF-tail beat frequency; OBF-opercula beat frequency, and mort. - Cumulative mortality (\%), ns-non-significant, F-testsignificant level:*-0.5, ${ }^{* *}-$ $0.01,{ }^{* * *}-0.001$.

Table 4: Lethal concentration and associated 95\% confidence limits of P.Papilio exposure to Sodium bromide

\begin{tabular}{|c|c|c|c|}
\hline Time (hrs) & Lethal Concentration (mean +C.L.) & Safe Concentration & Probit model estimation equation \\
\hline $\mathbf{2 4}$ & LC50- 20.81 (19.58-22.48) & 2.08 & \\
\hline $\mathbf{2 4}$ & LC90-26.44 (24.45-31.47) & 2.64 & $\mathrm{y}=-5.18+0.29^{\prime}$ \\
\hline $\mathbf{4 8}$ & LC50- $18.50(16.67-19.40)$ & 1.85 & $\mathrm{y}=-5.30+0.31^{\prime}$ \\
\hline $\mathbf{4 8}$ & LC90- $22.54(20.88-26.09)$ & 1.71 & $\mathrm{y}=-5.06+5.06^{\prime}$ \\
\hline $\mathbf{7 2}$ & LC50- $17.11(16.30-17.84)$ & 2.14 & \\
\hline $\mathbf{7 2}$ & LC90- $21.44(20.59-23.31)$ & 1.59 & 1.2 \\
\hline $\mathbf{9 6}$ & LC50-15.88 (14.99-16.64) & & \\
\hline
\end{tabular}

Where $y=$ dependent variable, $x=$ undependable variable 


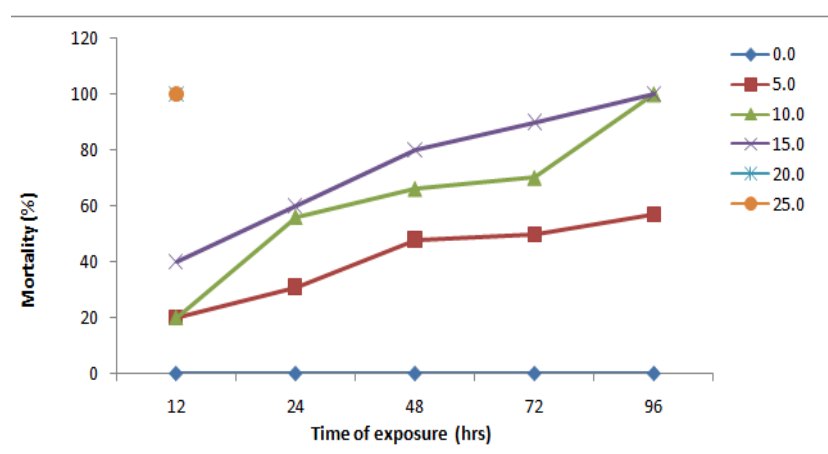

Figure 3: Mortality of P.papillio exposed to various concentrations of sodium bromide for 96 hours

\section{Lethal Concentration (LC) of Sodium bromide to $P$. pappilio for 96 hours}

The lethal effects of bromide on P. Papilio exposed to LC5, LC50 and associated 95\% confidence limits of the toxicant concentration as shown in table 4, indicated that the range of the values between $24 \mathrm{hrs}$ LC50 and $96 \mathrm{hr}$ LC50 was narrow. A safe concentration at LC50 of bromide to P.Papilio was very high ( $2.08 \mathrm{mg} / \mathrm{l}$ for 24 hours and $1.20 \mathrm{mg} / \mathrm{l}$ for 96 hours). The toxicity factor (T.F) of the various concentrations increased with time of exposure from 24 to 96 hours as indicated by the observed decreased in LC50 value. At 24 hours LC50 T.F recorded was 1.0 while 96 hours LC50 was 1.26 .

\section{Discussion}

Four major phases have been identified in the responses of fish to toxicants; the contact phase (brief period of excitability), exertion (visible avoidance characterized by fast swimming, leaping, and an attempt to jump out of the toxicant), loss of equilibrium and lethal (death) phase, when opercula movement and response to tactile stimuli cease completely [19]. Rao [20] reported the same Behavioural responses in C. gariepinus and other fish species exposed to acute concentrations of toxicants. The abnormal response such as hyperactivity increased ventilator rate, dash and erratic swimming, increased surfacing and other abnormal behaviors may have increased the energy demand for metabolism beyond normal, leading to fatigue and stress [21].

The stressful behavior responses of the exposed P.papilio suggest that they suffered respiratory impairment due to the effect of the biocide on the gills and general metabolism. Oxygen exchange across the gills might have been impaired as evidenced by the disruption of the structure of the gills and increased mucus production by mucus cells in exposed fish. These observations are in line with those of previous workers who assessed the acute effects of Cazmirm chloride and sodium bromide [22]. They attributed these behaviours to nervous disorder elicited by the toxicants.

Contamination of aquatic environment by biocide poses a series threat to aquatic life forms. The $24^{\mathrm{hr}} \mathrm{LC} 50$ value of sodium bromide to P. Papilio was found to be $2.64 \mathrm{mg} / \mathrm{l}$, indicating that sodium bromide is toxic to fish. The toxicity of sodium bromide varies depending on the fish species [23].This result is in line with that of Anees [24], in Channa punctatus exposed to insecticide in the laboratory. The toxicity of bromide in fish is traceable to a combination of three factors, a sensitive central nervous system, slow hydrolytic detoxification and direct absorption via the gills into the blood stream [25]. Furthermore biocide may also secondarily induce on osmotic imbalance that contributes to their toxicity [26]. Due to neurotoxin effect, sodium bromide might have affected the synthesis process regulation in nerve cells [27].

During chronic exposure of $P$. papillo to high doses of sodium bromide, the fish shows changes in its behavioural attitude, drastic variation in opercula beat rates, loss of its equilibrium, sluggish and settlement at the bottom. These ultimately led to respiratory distress paralysis and mortality especially at higher concentrations. The dead mudskipper was covered with a layer of mucous on the surface of the body. The hypersensitivity of the fish to biocide toxicity may be due to specie specific differences in biocide metabolism, however high sensitivity of the piscine nervous system to toxicants might be the possible reason [28].

The response pattern of tail beat frequency of exposed fish with respect to time and concentration of the biocide in this study agrees with the findings of Viran et al. [29] who studied the acute effects of deltamethrin on guppies (Poecilia reticulate). But it differed from the findings of Hoentella et al., [30] in rainbow trout exposed to cadmium salts. In these studies the values of TBF appeared to increase with time and concentration of the toxicant. The mode of action of biocide on the exposed fish may include impairment of nerve impulse transmission as was the case in fishes exposed to monocotophos, an organic phosphate insecticide [31].The generally low levels and less variable values of the TBF recorded in this study may suggest that the fish was less sensitive to the biocide when compared to the response of $C$. gariepinus exposed to cypermerthrin (pyrethroid) possibly due to its mode of action and size of fish [32]. Haphazard response and cessation of TBF before OBF, and subsequent death may indicate the trend in available metabolic energy. This appears to be the usual trend in the responses of $C$. gariepinus to acute concentrations of toxicants [33].

OBF appeared to be a more responsive parameter in measuring behavioural toxicity in comparison to TBF in $C$. gariepinus exposed to Roundup. The trend in OBF in this study and several others is that it is usually raised, peaks and then falls with time for the various concentrations of the toxicants tested [34]. However, variations observed in this study could be accounted for by differences in the fish species, life stage and mode of action of the toxicant. Obomanu et al. [35] observed that increased opercula rate may result from decreased efficiency in oxygen uptake, transport or increased metabolic rate. To cope with stress caused by exposure to the herbicide, the fish may have increased its TBF and OBF concurrently, but the latter particularly to increase the rate of water flow over the gills to enhance oxygen uptake from the water [36]. 
In this study, P. pappillis exposed to acute concentrations of Sodium Bromide exhibited an increased in pigmentation of the skin. According to Anderson [37] a layer of mucus (glycoproteins, preteoglycans and proteins) forms the interface between the skin of the fish and the external environment in addition to scales in scaly fish. The layer is continuously replenished by mucus secreting cells and the rate can increase in response to infection, chemicals or physical irritants. In this study, exposed fish had a greater amount of mucus covering their bodies and gills than that in the control. Mucus production is response to an irritant like Sodium Bromide is one of the strategies of fish to protect itself against damage, but this has grave implications particularly for the gills as this impairs oxygen uptake. Increased mucus as a result of increased activity of mucus cells was reported in C. gariepinus on exposured to petroleum products [34]. And Cirrhinus mrigala 0 exposed to cypermethrin.

\section{Conclusion}

This study proved that exposure to sodium bromide did not affect the water quality parameters except the dissolved oxygen which reduced, also chloride and electrical conductivity increased with increasing concentration of the chemical. In the toxicity LC50 (96hr) value of sodium bromide for P. papilio was found to be 1.59 indicating that sodium bromide is moderately toxic to the fish. There was a rapid response after the fish had contact with the biocide, as indicated by imbalance or disturbances in the studied biomarkers.

\section{References}

1. Abbas H, Mahmouz H, Matty S. Haematological and biochemical changes in Oreochromis aureus and Claries gariepinus exposed to mixture of copper and lead salts. Egyptian Journal of Basic and Applied Physiology .2004;3:89-106.

2. Gabriel UU, Uedeme-Naa B, Akinrotimi OA. Pollutant induced altered behaviours in fish: A review of selected literature. Journal of Technology and Education in Nigeria (JOTEN). 2011;16(1):9-23.

3. Edun OM, Makinde OO, Akinrotimi OA. Comparative Assessment of Physical and Chemical Characteristics of water in Ekerekana and Buguma Creeks, Niger Delta, Nigeria. Journal of Environmental Protection and Sustainable Development. 2015;1(3):126 - 133.

4. Akinrotimi OA, Edun OM, Makinde 0O. Seasonal variation of heavy metals in selected sea foods from Buguma and Ekerekana creeks. Niger delta International. 2015

5. Farombi E, Adelowo 0, Ajimoko Y. Biomakers of oxidative stress and heavy metal levels as indicator of environmental pollution in African catifish (Clarias gariepinus) from Ogun River, Nigeria. International Journal of Environmental Research and Public Health. 2007;4(2):158 -165 .

6. Ananth S, Mathiveran S, Aravith S, Sangectha V. Impact of arsenic metal toxicant on biochemical changes in the grass carp Ctenopharynagodon idella. International Journal oj Modern Research and Reviews. 2014;2(2): 74-78.

7. Das B, Mukherjee S. Toxicity of cypermethrin in Labeo rohita. Fingerlings: biochemical enzymatic and haemotological consequences. Comperative Biochemistry physiology C. 2003;134:109-121
8. Ernst B, Hoeger SJ, O Brien E, Dietrich DR. Physiological stress and pathology in European Whitefish (coregonus lavaretus) induced by subchronic exposure to environmentally relevant densities of plandtothrix rubescens. Aquatic toxicology. 2007;82(1):15-26. doi: 10.1016/j.aquatox.2007.01.007.

9. AlGlalnim KA. Effect of cypermmethrin toxicity on enzyme activities in the fresh water fish, Cyprirus carnio. African Journal of Biotechnology. 2014;13(10):1169-1173.

10. Benli AG, Koskal G, Ozkal A. Sublethal ammonia exposure of Nile tilapia Oreochromis niloticus. Effect on gill, liver and kidney histology. Chemosphere. 2007; 72(9):1355-1358. doi.org/10.1016/j. chemosphere.2008.04.037

11. Ntegwe FW, Maseka KK. The impact of effluents containing zinc and nickel metals on stream and river water bodies. Journal of Environmental Sciences. 2006;42:321-327. Doi: 10.1016/j. pce.2006.08.027

12. Oluah NS, Chineke AC. Alterations in the biochemical parameters of the African catfish Clarias garicpinos exposes to sublethal concentration of lanzacyhalothrin. Annas of Environmental science 2014;8:1-7

13. Ogundele OM, Caxton-Martins EA, Ghazab, OK, Jimoh OR. Phosphatase profile in Manhot esculanta induced neurotoxicity: role in neuronal degeneration in the brain of adult wister rats. Journal of Cell Animal Biology. 2010; 4(9):131 - 136.

14. Okuku EO, Peter HK. Use of Heavy metal pollution biomonitors. International Journal of Environmental Research 2012;6(1):313 322.

15. Abedi Z, Khalesi MK, Kohestan ES, Rahamani H. Comparison of lethal concentrations of $\mathrm{Pb}$ No3 in common carp. Iranian Journal of Toxicology. 2012;6(17):672 - 680.

16. Coimbra AM, Reis-Henriques MA, Daraas VM. Circulating thyroid hormone levels and iodothyronine deiodinase activities in Nile tilapia (Oreochromis niloticus) following dietary exposure to endosulfan and aroclorm 1254. Comp Biochemistry Physiology C. 2005;141(1):8-14. doi.org/10.1016/j.cca.2005.04.006

17. Begum G. In vivo biochemical changes in liver and gill of Clarias batrachus during cypermethrin exposure and following cessation of exposure, Pestiology Biochemistry physiology. 2005;82(3):185-196. doi.org/10.1016/j.pestbp.2005.02.006

18. APHA-AWWA-WPCF. Standard methods for the Examination of water and Wastewater, 20th edition American Public Health Association: New York. 1998

19. Das P, Ayyappan S, jena J, Das B. Acute toxicity of ammonia and its sub lethal effects on selected haematological and enzymatic parameters of mrigal, cirrhinus mrigala (Hamilton). Aquatic Research. 2004;35(2):134-143. DOI: 10.1111/j.1365-2109.2004.00994.x

20. Rao JV. Effects of monocrotophos and its analysis in acetylcholinestoase activities inhibition and its pattern of recovery on evryhaline fish, (Oreochromis mossamicus). Ecotoxicology Environmental Safety. 2004.59(2):217-222.

21. Chang M, Yang CW, Chen JC, Ho PY, Lin DY, Lin CH, et al. Disproportional exaggerated aspartate transaminase is a useful prognostic parameter in Later lepiospirosis. World Journal of Gastroenterol. 2005;11(35):5553 $-5556$. 
22. Atamanalp M, Keles MS, Haliloglu HL, Aras MS. The effects of cypermethrin (a synthethic pyrethroid) on some biochemical parameters (Ca, P, Na and TP) of rainbow trout (Oncorhynchus mykiss). 2002;26:1157-1160.

23. Anusuya L, Hemalatha O. Effect of 2, 4-D pesticide on fish physiology and its antioxidant stress. World Journal of Fish and marine Sciences. 2014;6(1):98-100.

24. Anees MA. Acute toxicity of four four organophosphorous insecticides to a fresh water teleost channa punctatus (Bloch). Pakistan Journal of Zoology. 2005;7:135-141.

25. Gaber HS, Abbas WT, Mohammed MN, Gabes SA. Histological and biochemical studies on some organs of two fish species in Bardawil lagoon North Sinai Egypt. Glosal Veterinaria. 2014;12(1):1-11. DOI: 10.5829/idosi.gv.2014.12.01.76199

26. Karatas S, Kalay M. Accumulation of lead in the gill, liver, kidney and brain tissue of Tilapia zilli. Turk J Vetinary Animal Science. 2002;26:471-477.

27. Kharat PS, Ghoble LB, Slejule KB, Ghoble BC. Effect of TBTCL on glycogen profile in fresh water prawn, Macrobrachium kistensis. World Applied Science Journal. 2009;7(2):1534-153.

28. Lu SY, Wang F. Damage to hepatic thyroxine 5'-deopdination induced by pathogenic factors od Kesahan disease and the preventive effects of selenimum and vitamin E. Biomed. Environmental Science. 1992;4:359-365.

29. Viran R, Erkoc FU, Polat H, Kocak O. Investigation of acute toxicity of deltamethrin on guppies (Poecitia reticulate). Ecotoxicology and Environmental Safety. 2003;55(1):82-85. doi.org/10.1016/S01476513(02)00096-9

30. Hontela A, Daniel C, Richard AC. Effects of acute and subacute exposures to cadmium on the interregnal and thyroid function in rainbow trout Oncorhynchus mykiss. Aquatic Toxicology. 1996;35(3):171 - 182.
31. Velma V, Vutukuru S, Tehovawov PB. Ecotoxicology of hexavelent chromium in freshwater fish: a critical review. Reviews on Environmental Health. 2009;24(2):129 - 146.

32. Omoniyi I, Agbon AO, Sodunke SA. Effect of lethal and sublethal concentrations of tobacco (Nicotiana tobaccum) leaf dust extracts on weight and haematological changes in Clarias gariepinus. Journal of Applied Science and Environmental Management. 2002;6(2):37 - 41. DOI: $10.4314 /$ jasem.v6i2.17174

33. Gabriel UU, Obomanu FG, Edori OS. Biochemical changes in hybrid catfish treated with nuracron. Chinese Journal of Environmental Biology. 2010;16(3):6 - 25. DOI: 10.3724/SP.J.1145.2010.00353

34. Gabriel UU. Amakiri NE, Ezeri GNO. Haematology and gill pathology of Clarias gariepinus exposed to refined petroleum oil, kerosene under laboratory conditions. Journal of Animal and Veterinary Advances. 2007;6(3):461 - 465 .

35. Obomanu FG, Ogbalu OK, Gabriel UU, Fekaruhodo SGB, Abadi SU. Piscidal effects of Lepidogathic alopneuroides on mudskipper periothatmus papilio from the Niger Delta. Research Journal Applied Science. 2007;2(4): 382 - 287.

36. Adams SM, Ham KD, Greely KS, Sayler CF. Downstream gradients in bioindicator responses point source contamination effects of fish health. Canadian Journal of Fisheries and Aquatic Science. 1996;53:2177-2187. doi.org/10.1139/f96-191

37. Anderson T, Fortin L, Handing J, Lorsan A. Physiological disturbances in fish living in Coastal water polluted with bleached kraft mill effluents. Canadian Journal of Fisheries and Aquatic Science. 1988;45(9):1525 doi.org/10.1139/f88-181 - 1536

38. Preshantha MS, Neclagund SE. Impact of cypermethrin on ezyme activities in the fresh water fish Cirrhinus mrigala. Casipian Journal of Environmental Science. 2008;6(2):91-95 